\title{
The Arabic Version of MELASQoL Scale: Translation, Cultural Adaptation, with Assessment of Reliability and Validity
}

\author{
Doaa AE Abou-Taleb ${ }^{1}$, Alaa EA Moubasher ${ }^{1}$, Ahmed K Ibrahim², Eman MK Youssef ${ }^{1}$ \\ ${ }^{1}$ Department of Dermatology, Venereology, and Andrology, Faculty of Medicine, Assiut University, Assiut, Egypt \\ ${ }^{2}$ Department of Public Health and Community Medicine, Faculty of Medicine, Assiut University, Assiut, Egypt
}

*Corresponding Author: Abou-Taleb DAE, Department of Dermatology, Venereology, and Andrology, Assiut University Hospital, 71515 Assiut, Arab Republic of Egypt. Email: doaa_aboutaleb@aun.edu.eg, dodda_aboutaleb @yahoo.com

Received date: June 29, 2021; Accepted date: July 09, 2021; Published date: July 13, 2021

Citation: Abou-Taleb DAE, Moubasher AEA, Ibrahim AK, Youssef EMK. (2021) The Arabic Version of MELASQoL Scale: Translation, Cultural Adaptation, with Assessment of Reliability and Validity. Dermatology and Dermatitis. 6(2); Doi: 10.31579/2578-8949/079

Copyright: @2021 Abou-Taleb DAE, This is an open-access article distributed under the terms of The Creative Commons. Attribution License, which permits unrestricted use, distribution, and reproduction in any medium, provided the original author and source are credited.

\begin{abstract}
Background: Melasma has significant emotional and psychological effects and significant negative impact on patients' quality of life (QoL). Melasma QoL Scale (MELASQoL) is a specific questionnaire that has been developed to assess the effect of melasma on patient's QoL.

Objective: Translation, cultural adaptation, reliability and validation of melasma specific QoL sale (MELASQoL) into Arabic.

Patients and Methods: A total of 65 adult Egyptian female patients with melasma aged $\geq 18$ years old with skin phototypes type III-V were enrolled in this study. Wood's light was used for determination of the type of melasma either epidermal, dermal or mixed. Melasma severity was assessed by using the melasma area and severity index (MASI) score and the new modified score (mMASI). The impact of melasma on QoL was evaluated using the Arabic version of MELASQoL scale after translation and cultural adaptation according to the WHO guidelines. The questionnaire's reliability and validity was assessed.

Results: The internal consistency for the 10-item of the MELASQoL-A scale was excellent; Intra-class Correlation Coefficient $(\mathrm{ICC})=0.914$ and Cronbach's alpha coefficient (Cronbach $\alpha=0.944$ ) indicating high reliability of the developed Arabic version. There was significant positive correlation between the MELASQoL-A scale and the MASI score $(r=0.41 ; p=0.0027)$, and the mMASI score $(r=0.36 ; p=0.0032)$.

Conclusion: The Arabic version of the MELASQoL scale was found to be a reliable and valid measure for evaluating the QoL among Egyptian melasma patients, supporting its use in Arab communities.

Keywords: melasma; quality of life; questionnaire; reliability; validity
\end{abstract}

\section{Introduction}

Quality of life (QoL) is a term which involves many items, including social well-being, psychosocial and family relationships [1,2].

Many dermatological diseases are characterized by compromising patients' physical and relational well-being. For this reason, the assessment of QoL is of great importance [3, 4].

Most questionnaires used to assess the QoL were developed for English speaking populations. So, they are not adequate in terms of correct translation to the reality of other countries. These questionnaires have to be translated and culturally adapted in order to be applied for each specific community $[5,6]$.
Melasma is a common cosmetic problem. It is an acquired, chronic, recurrent hyperpigmentary disorder, which is characterized by brown patches of variable darkness on sun exposed areas of the body, typically occurs on the face. It is more common in women, and appears in all racial types. It is found mostly in women with Fitzpatrick skin photo-types IV and $\mathrm{V}$ living in areas of marked ultraviolet ray's exposure $[7,8]$.

It has a significant emotional and psychological effects and highly compromises patients' QoL. It is usually psychologically distressing and affects patients' social interactions [9]. 
A new health-related quality of life (HRQoL) questionnaire for melasma, a melasma specific scale which is Melasma Quality of Life Scale (MELASQoL) has been developed (English version) [10].

The Dermatology Life Quality Index (DLQI) and SKINDEX-16 are general questionnaires of the impact of skin disease on the HRQoL of patients with different skin diseases; they put equal weight on the psychological and physical effects of a dermatological condition. The developed MELASQoL scale uses items from the SKINDEX-16 and the skin discoloration questionnaire, which focus on items that would be more relevant to melisma [10].

MELASQoL is a 10 question scale, which asks patients to rate how they feel about each issue on a scale from 1 (not bothered at all) to 7 (bothered all the time). The score obtained in the answers ranges from 10 to 70 with the higher scores indicating the worst QoL $[10,11]$. This questionnaire has been translated into Spanish [11], Brazilian Portuguese [12, 13], French [14] and Turkish [15] languages. However, there is no available Arabic version of that questionnaire to assess the melasma patients' QoL in Arab communities where melasma is a common distressing disease.

The objectives of this study were to translate and to adapt the MELASQoL scale to Arabic language, and to assess the reliability and validity of the Arabic version of the (MELASQoL-A) scale.

\section{Patients and methods}

This cross-sectional study was conducted at the department of Dermatology, Venereology and Andrology, Assiut University Hospital (AUH), Assiut, Egypt. The study design was approved by the Institutional Ethics and Research Committee of the Faculty of Medicine, Assiut University and was carried out in accordance with the guidelines of the Helsinki Declaration.

A total of 65 adult female Egyptian patients with melasma aged $\geq 18$ years old, with Fitzpatrick skin photo-types III-V were randomly recruited from dermatology outpatient clinic of AUH. They were included in the study after signing the informed consent form. A detailed history regarding age, occupation, marital status, residence, duration of complaints, precipitating, exacerbating factors and family history were taken. A dermatologic examination was performed to clinically classify the type of melasma into centrofacial, malar, or mandibular patterns. The severity of melasma was determined for each patient using Melasma Area and Severity Index (MASI) score ${ }^{16}$ and the modified (mMASI) score $[8,17]$.

The impact of melasma on QoL was assessed using the Arabic version of the questionnaire (MELASQoL-A) after translation and cultural adaptation.

Development of the Arabic version of the MELASQoL followed the World Health Organization (WHO) guidelines for scale development as follows [5,6,11]: Forward translation, expert panel back-translation, pretesting and cognitive interviewing, development of the final version.

\section{1) Forward translation}

Two translators produced independent Arabic-language translations of the English version of MELASQoL questionnaire, the translated version has been reviewed by a committee of experts who developed a unique Arabic language translation and modified some items to make them more culturally appropriate. Some changes were made, for example, "melasma" was substituted for "skin condition" because the latter term might be interpreted as meaning another skin disease. Finally, the face validity of the questionnaire was confirmed by its application on a sample of patients using an interview technique. The patients who were interviewed, expressed their well-understanding for the each item of the MELASQoL questionnaire.

\section{2) Expert panel back-translation}

A back-translation (from Arabic to English) was performed by other two translators, to verify that the original questionnaire could be reinstated without any major modification and without alteration of the original items and few changes were made, for example, "Frustration and affection" were back translated to "Disappointment and emotion" respectively. This back-translation was submitted to the developer of the original questionnaire (Balkrishnan, R) [10] for review and comments and he agreed and approved the back translation.

\section{3) Pre-testing and cognitive interviewing}

Qualitative pre-testing of the revised Arabic version of the MELASQoL was carried out with 20 Egyptians female patients with melasma to determine whether each question was correctly understood, patients were asked to justify their answers and explain what the questions meant in their own words.

\section{4) Final Arabic version}

Reliability and validity of the final Arabic version (MELASQoL-A) scale have been conducted.

Finally, the Arabic version of the MELASQoL questionnaire (as shown in the appendix) was distributed to a total of 65 female patients with melasma. On a 7-point Likert scale; 1 (not bothered at all) to 7 (bothered all the time). Each patient rates how she feels about each item. The total MELASQoL-A score ranges from 10 to 70 with higher score indicating worse QoL related to melasma.

\section{Statistical analysis}

All analyses were carried out using using SPSS version 21. Internal consistency of the scale was assessed using Cronbach's alpha coefficient. Item analysis was performed, and Cronbach $\alpha[18,19]$ was calculated for the total MELASQoL-A scale and for separate domains. Confirmatory Factor Analysis (CFA) was conducted to confirm the separate factors within the scale. Each item within a factor was judged to be worthy of retention in a scale according to its power to explain variation between subjects. To study the construct validity of the scale, Spearman's Rank Correlation coefficient was used to test for any association between MELASQoL-A score, MASI score and mMASI score with age, marital status, occupation, residence and clinical type of melasma. As regards $\mathrm{p}$ value; $\mathrm{p}<0.05$ was considered statistically significant.

\section{Results}

A 65 adult Egyptian female patients with melasma participated in the study. The age of these patients ranged from 20 to 52 years old with a mean $+\mathrm{SD}$ of $(35 \pm 7.3)$. The proportion of women $\leq 40$ years old was 53 patients $(81.5 \%)$, and those $>40$ years old 12 patients $(18.5 \%)$. The duration of melasma ranged from 1-10 years with a mean \pm SD of ( $4 \pm$ 2.5). The demographic data of the study is shown in (Table 1).

\begin{tabular}{|c|c|}
\hline Item & Result \\
\hline $\begin{array}{c}\text { Age (years): } \\
\text { Mean } \pm \text { SD } \\
\text { range }\end{array}$ & $\begin{array}{l}35 \pm 7.3 \\
20-52\end{array}$ \\
\hline $\begin{array}{ll}\text { Sex: } & \\
& \text { Female }\end{array}$ & $65(100 \%)$ \\
\hline
\end{tabular}




\begin{tabular}{|c|c|}
\hline Male & $0(0 \%)$ \\
\hline $\begin{array}{r}\text { Marrital status: } \\
\text { Married } \\
\text { Unmarried }\end{array}$ & $\begin{array}{l}57(88 \%) \\
8(12 \%)\end{array}$ \\
\hline $\begin{array}{l}\text { Occupation: } \\
\text { Working } \\
\text { Non-working }\end{array}$ & $\begin{array}{l}9(14 \%) \\
56(86 \%)\end{array}$ \\
\hline $\begin{array}{c}\text { Residence: } \\
\text { Rural } \\
\text { Urban }\end{array}$ & $\begin{array}{l}55(85 \%) \\
10(15 \%)\end{array}$ \\
\hline $\begin{array}{r}\text { Family history } \\
\text { Positive } \\
\text { Negative }\end{array}$ & $\begin{array}{l}14(22 \%) \\
51(78 \%)\end{array}$ \\
\hline $\begin{array}{c}\text { Duration of melasma (years) } \\
\text { Mean } \pm \text { SD } \\
\text { Range }\end{array}$ & $\begin{array}{l}4 \pm 2.5 \\
1-10\end{array}$ \\
\hline $\begin{array}{r}\text { Skin type: } \\
\text { Type III } \\
\text { Type IV } \\
\text { Type V }\end{array}$ & $\begin{array}{l}5(7.8 \%) \\
58(89.2 \%) \\
2(3 \%)\end{array}$ \\
\hline $\begin{array}{l}\text { Clinical type of melasma } \\
\text { Centrofacial melasma } \\
\text { Malar } \\
\text { Mandibular }\end{array}$ & $\begin{array}{l}51(78.5 \%) \\
14(21.5 \%) \\
0(0 \%)\end{array}$ \\
\hline
\end{tabular}

$\mathrm{SD}=$ standard deviation

Table 1: Demographic data of the study

The distribution of the MELASQoL-A scale among all Interval for Mean (59.0-64.17) and ranged from 30 to 70 . The spread of patients scores was not normally distributed (skewness $=-1.75$ and kurtosis $=$

The distribution of the MELASQoL-A for the 65 patients is shown in 2.6).

(Table 2 and Fig. 1). The mean was $61.58(\mathrm{SD}=10.45), 95 \%$ Confidence

\begin{tabular}{|l|l|}
\hline MELASQoL Scale & Statistics \\
\hline Mean & 61.58 \\
\hline 95\% Confidence Interval for Mean & $59.0-64.17$ \\
\hline $\mathbf{5 \%}$ Trimmed Mean & 62.85 \\
\hline Median & 66 \\
\hline Range & $30-70$ \\
\hline Std. Deviation & 10.45 \\
\hline Inter-quartile Range & 9 \\
\hline Skewness & -1.75 \\
\hline Kurtosis & 2.6 \\
\hline Cronbach's $\alpha$ & 0.944 \\
\hline Ferguson $\boldsymbol{\delta}$ & 1.0006 \\
\hline
\end{tabular}

Table 2: Statistical Properties of the Arabic version of the Melasma Quality of Life Scale (MELASQoL-A) 


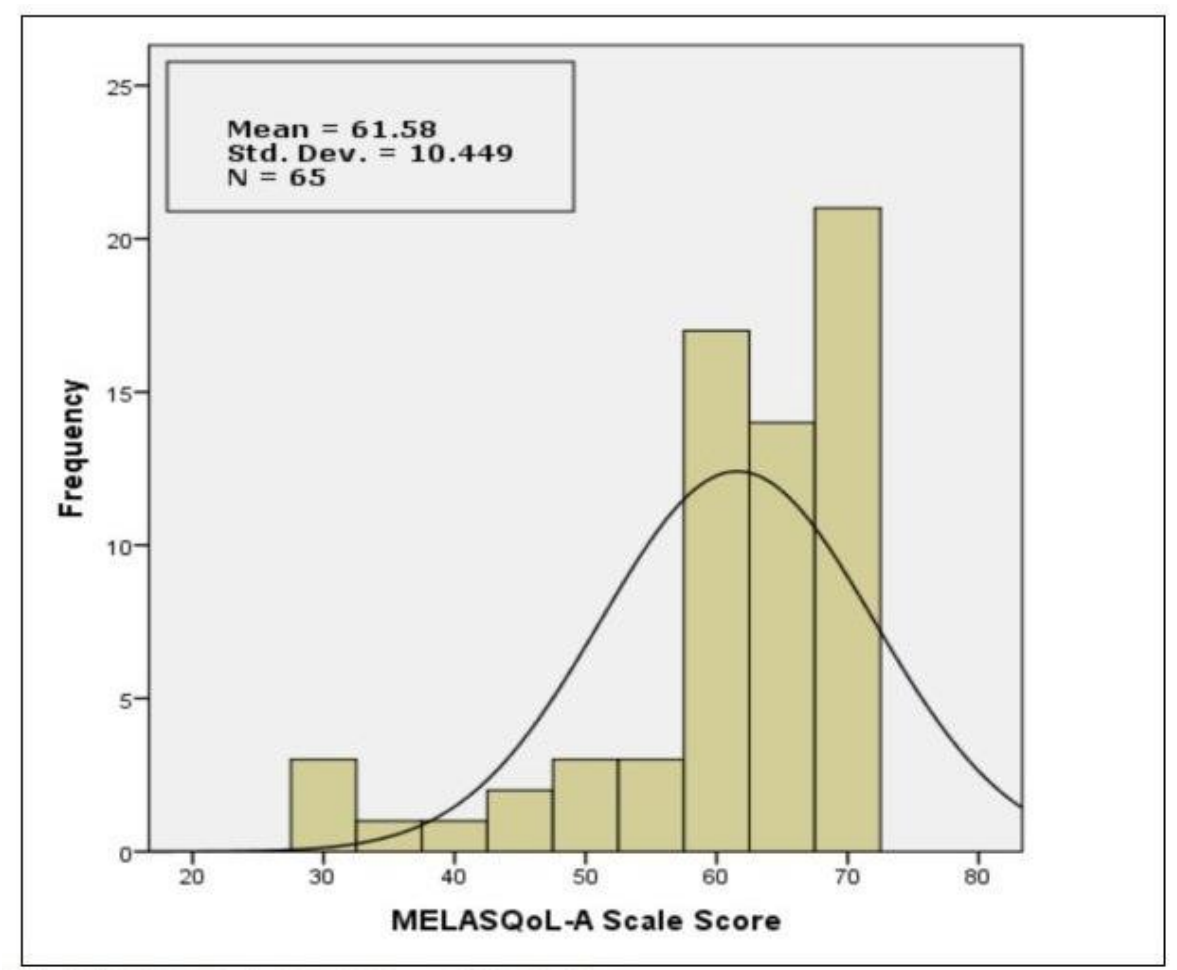

Figure 1: MELASQoL-A Scale Scores Distribution.

\section{Scale reliability}

The internal consistency for the 10-item of the Arabic version of the questionnaire MELASQoL-A was excellent; Intra-class Correlation Coefficient (ICC) $=0.914$ and Cronbach's alpha coefficient (Cronbach $\alpha$ $=0.944$ ) indicating high reliability of the developed Arabic version. The
10 items of the MELASQoL-A scale showed high item-total correlations $(>0.3)$ and high Cronbach $\alpha(>0.6)$. Reliability statistics for the main domains of the 10 items of MELASQoL-A scale were satisfactory, ranging from acceptable (>0.5) to very good (between 0.8 and 0.9 ) as expressed by (Table 3). However, Cronbach $\alpha$ for the total scale $=0.944$ was not improved by removal of any of the items [20].

\begin{tabular}{|c|c|c|}
\hline Question & Item & $\begin{array}{l}\text { Item-Total } \\
\text { Correlation* }\end{array}$ \\
\hline Q1 & The appearance of your skin condition & 0.686 \\
\hline Q2 & Frustration about your skin condition & 0.686 \\
\hline Q3 & Embarrassment about your skin condition & 0.602 \\
\hline Q4 & Feeling depressed about your skin condition & 0.709 \\
\hline Q5 & $\begin{array}{l}\text { The effects of your skin condition on your interactions with } \\
\text { other people }\end{array}$ & 0.856 \\
\hline Q6 & The effects of your skin condition on your desire to be with people & 0.856 \\
\hline Q7 & Your skin condition making it hard to show affection & 0.884 \\
\hline Q8 & Skin discoloration making you feel unattractive to others & 0.648 \\
\hline Q9 & Skin discoloration making you feel less vital or productive & 0.773 \\
\hline Q10 & Skin discoloration affecting your sense of freedom & 0.833 \\
\hline \multicolumn{3}{|c|}{ Cronbach's alpha $=0.944$} \\
\hline \multicolumn{2}{|c|}{ ICC $(95 \% \mathrm{CI}) * *$} & \\
\hline
\end{tabular}

$*<0.3$ considered to be low item-total correlation

** ICC $(95 \% \mathrm{CI}) * *=$ Intra-class Correlation Coefficient (95\% Confidence Interval) 
For the first scale domain (emotional well-being), that contained 4 items, Cronbach $\alpha=0.930$ and ICC $=0.915$. While the second domain (social life), that had 3 items, had Cronbach $\alpha=0.971$ and ICC $=0.971$. The last domain (Recreation \& leisure), that contained 3 items had Cronbach $\alpha=$ 0.800 and $\mathrm{ICC}=0.834$, as shown in (Table 4$)$.

The original MELASQoL scale (English version) proposed that melasma affects mainly three domains of QoL; emotional well-beings, social life and recreation and leisure [10].

The Arabic version (MELASQoL-A) was similarly found that melasma mostly affected patients' emotional well-beings (Cronbach $\alpha=0.930$ ) and social life (Cronbach $\alpha=0.971)$ and to lower extent recreation and leisure (Cronbach $\alpha=0.800$ ) as shown in (Table 4).

\begin{tabular}{|c|c|c|}
\hline Domain & Item & Item-Total \\
\hline \multirow{5}{*}{ 预 } & \multirow{2}{*}{ The appearance of your skin condition } & 0.895 \\
\hline & & Correlation* \\
\hline & Frustration about your skin condition & 0.895 \\
\hline & Embarrassment about your skin condition & 0.806 \\
\hline & Feeling depressed about your skin condition & 0.715 \\
\hline \multicolumn{3}{|c|}{ Domain Cronbach's alpha $=\mathbf{0 . 9 3 0}$} \\
\hline \multicolumn{2}{|c|}{ ICC $(95 \% \mathrm{CI}) * *$} & $0.915(0.875-0.944)$ \\
\hline \multirow{3}{*}{ 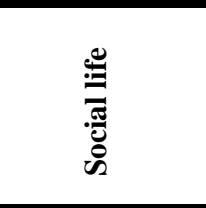 } & $\begin{array}{l}\text { The effects of your skin condition on your interactions with } \\
\text { other people }\end{array}$ & 0.962 \\
\hline & $\begin{array}{l}\text { The effects of your skin condition on your desire to be with } \\
\text { People }\end{array}$ & 0.954 \\
\hline & Your skin condition making it hard to show affection & 0.896 \\
\hline \multicolumn{3}{|c|}{ Domain Cronbach's alpha $=0.971$} \\
\hline ICC $(95 \% \mathrm{CI})$ & \multicolumn{2}{|l|}{\begin{tabular}{|l|l|} 
& $0.971(0.956-0.981)$ \\
\end{tabular}} \\
\hline \multirow{3}{*}{ 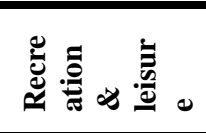 } & Skin discoloration making you feel unattractive to others & 0.641 \\
\hline & Skin discoloration making you feel less vital or productive & $\mathbf{0 . 8 2 7}$ \\
\hline & Skin discoloration affecting your sense of freedom & 0.706 \\
\hline \multicolumn{3}{|c|}{ Domain Cronbach's alpha $=\mathbf{0 . 8 0 0}$} \\
\hline \multicolumn{2}{|r|}{$0.834(0.699-0.872)$} & \\
\hline
\end{tabular}

$*<0.7$ considered to be low item-total correlation.

\section{Table 4: Internal consistency of the MELASQoL-A scale original domains}

\section{Factor analysis}

Factor analysis was therefore conducted with all 10 items. The first factor (factor I) (4 items, corresponding to emotional well-being) explained $66.4 \%$ of the variance, the second factor (factor II) (3 items, corresponding to social life) explained $14.9 \%$ of the variance, the third factor (factor III) (3 items, corresponding to recreation \& leisure) accounted for $7.9 \%$ of the variance, as shown in (Table 5). The results of Confirmatory Factor Analysis Scree Plot using Principle Component Analysis, confirmed that the main scale domain has a "leveling off" of eigenvalues after the first factor (factor I) (Fig. 2).

\begin{tabular}{|c|c|c|c|}
\hline \multirow{2}{*}{ Question } & \multicolumn{3}{|c|}{ Factor* } \\
\hline & I & II & III \\
\hline Q1- The appearance of your skin condition & 0.907 & & \\
\hline Q2- Frustration about your skin condition & 0.907 & & \\
\hline Q3- Embarrassment about your skin condition & 0.905 & & \\
\hline Q4- Feeling depressed about your skin condition & 0.859 & & \\
\hline Q5- The effects of your skin condition on your interactions with other people & & 0.962 & \\
\hline Q6- The effects of your skin condition on your desire to be with people & & 0.961 & \\
\hline Q7- Your skin condition making it hard to show affection & & 0.962 & \\
\hline Q8- Skin discoloration making you feel unattractive to others & & & 0.970 \\
\hline Q9- Skin discoloration making you feel less vital or productive & & & 0.806 \\
\hline
\end{tabular}




\begin{tabular}{|c|c|c|c|}
\hline Q10- Skin discoloration affecting your sense of freedom & & 0.872 & \\
\hline$\%$ Variance & $66.4 \%$ & $14.9 \%$ & $7.9 \%$ \\
\hline
\end{tabular}

*Factor loadings $<0.6$ is suppressed (Results of Confirmatory Factor Analysis)

Table 5: Loading from Direct oblimin rotation matrix $(N=65)$

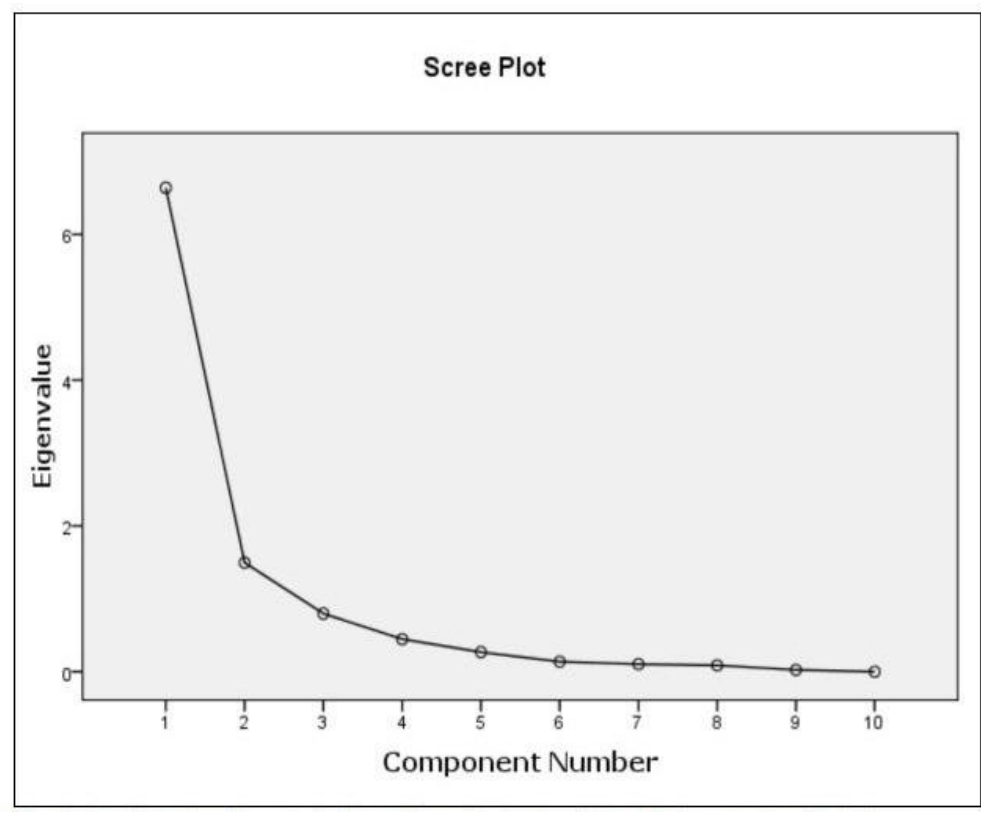

Figure 2: Confirmatory Factor Analysis Scree Plot using Principle Component Analysis.

\section{Construct validity of the MELASQoL-A scale}

The construct validity of the Arabic version of the questionnaire (MELASQoL-A) showed that higher MELASQoL-A scale scores was significantly correlated to rural residence (correlation coefficient; $r=$
$0.31)$, non-working patients $(\mathrm{r}=0.32)$ and those with centrofacial melasma $(r=0.43)$. There was significant positive correlation between the MELASQoL-A scale and the MASI score $(r=0.41 ; \mathrm{p}=0.0027)$, and the mMASI score $(\mathrm{r}=0.36 ; \mathrm{p}=0.0032)$, as shown in (Table 6$)$.

\begin{tabular}{|c|c|c|c|c|c|c|c|}
\hline & \multicolumn{7}{|l|}{ Number $(n=65)$} \\
\hline & $\begin{array}{l}\text { MELASQOL } \\
\text { Score }\end{array}$ & Age & $\begin{array}{l}\text { Marital } \\
\text { Status } \\
\end{array}$ & Residence & Occupation & $\begin{array}{l}\text { Clinical type } \\
\text { of melsma }\end{array}$ & mMASI Score \\
\hline $\begin{array}{l}\text { MELASQOL } \\
\text { Score }\end{array}$ & 1.000 & & & & & & \\
\hline Age & $\begin{array}{l}-0.13^{*} \\
(>0.05)\end{array}$ & 1.000 & & & & & \\
\hline Marital Status & $\begin{array}{l}-0.06^{*} \\
(>0.05)\end{array}$ & $\begin{array}{l}0.51^{*} \\
(<0.001)\end{array}$ & 1.000 & & & & \\
\hline Residence & $\begin{array}{l}0.31^{*} \\
(<0.01)\end{array}$ & $\begin{array}{l}0.40^{*} \\
(<0.01)\end{array}$ & $\begin{array}{l}0.16^{*} \\
(>0.05)\end{array}$ & 1.000 & & & \\
\hline Occupation & $\begin{array}{l}0.32^{*} \\
(<0.01)\end{array}$ & $\begin{array}{l}0.22^{*} \\
(<0.05) \\
\end{array}$ & $\begin{array}{l}0.02^{*} \\
(>0.05)\end{array}$ & $\begin{array}{l}0.57^{*} \\
(<0.001)\end{array}$ & 1.000 & & \\
\hline $\begin{array}{l}\text { Clinical type of } \\
\text { melasma }\end{array}$ & $\begin{array}{l}0.43^{*} \\
(<0.001) \\
\end{array}$ & $\begin{array}{l}0.12^{*} \\
(>0.05)\end{array}$ & $\begin{array}{l}-0.03 * \\
(>0.05) \\
\end{array}$ & $\begin{array}{l}-0.02 * \\
(>0.05) \\
\end{array}$ & $\begin{array}{l}0.01 * \\
(>0.05) \\
\end{array}$ & 1.000 & \\
\hline mMASI Score & $\begin{array}{l}0.36^{*} \\
(<0.01)\end{array}$ & $\begin{array}{l}0.09 * \\
(>0.05)\end{array}$ & $\begin{array}{l}0.02 * \\
(>0.05)\end{array}$ & $\begin{array}{l}-0.01 * \\
(>0.05)\end{array}$ & $\begin{array}{l}-0.002 * \\
(>0.05)\end{array}$ & $\begin{array}{l}0.45^{*} \\
(<0.001)\end{array}$ & 1.000 \\
\hline MASI Score & $\begin{array}{l}0.41^{*} \\
(<0.01)\end{array}$ & $\begin{array}{l}0.07^{*} \\
(>0.05)\end{array}$ & $\begin{array}{l}-0.01 * \\
(>0.05)\end{array}$ & $\begin{array}{l}-0.03 * \\
(>0.05)\end{array}$ & $\begin{array}{l}0.02 * \\
(>0.05)\end{array}$ & $\begin{array}{l}0.47^{*} \\
(<0.001)\end{array}$ & $\begin{array}{l}0.97^{*} \\
(<0.001)\end{array}$ \\
\hline
\end{tabular}

Table 6: Spearman's correlation between MELASQoL-A score, MASI score, MMASI score and Clinical Data.

\footnotetext{
*Spearman Correlation is significant at the 0.05 level (2-tailed).
} 


\section{Discussion}

Melasma is a common disorder of hyper-pigmentation affecting millions of people worldwide [7, 8] It may cause significant psychological distress and has a significant impact on the QoL [13].

This study discussed the Arabic version of the MELASQoL scale and evaluated its reliability and validity among Egyptian melasma patients. It was found that it is a reliable and valid measure for evaluating the QoL among Egyptian melasma patients, supporting its use in Arab communities. The Arabic version of the questionnaire was developed using a sample of patients mostly with skin type IV, so it provides information related mostly to this skin photo-type and to lower extent on the other skin phototypes.

The Arabic version of the MELASQoL questionnaire was easily understood and answered by the patients. The mean of MELASQoL-A score in this current study was 61.58 (Standard deviation $=10.45$ ), higher than that measured in an English speaking patients in a previous USA study was 36 [10], Brazilian patients was 37.5 [13], French patients was 20.9 [14] and Turkish patients was 29.9 [15] suggesting that Egyptian patients are at higher risk to suffer from negative emotional well-being and impaired social functions because of melasma.

The internal consistency for the 10 items of the developed Arabic version (MELASQoL-A) was excellent $(\mathrm{ICC}=0.914$ and Cronbach $\alpha=0.944)$. This reflects its usefulness and its high internal consistency to discriminate different domains of the patient's QoL. Our findings regarding the internal consistency and the scale reliability were approximate to those reported by Cestari et al. (2006) (Cronbach $\alpha=$ 0.919) of the Brazilian Portuguese version [12], by Misery et al. (2010) (Cronbach $\alpha=0.95)$ and $(\mathrm{ICC}=0.88)$ of the French Version of MELASQOL [14], and that reported by Dogramaci et al. (2009) (Cronbach $\alpha=0.88$ ) of the Turkish version [15].

Our results of the excellent internal consistency for the 10-item of the Arabic version of the questionnaire (MELASQoL-A); (ICC $=0.914$ and Cronbach $\alpha=0.944$ ) and the results of Confirmatory Factor Analysis Scree Plot using Principle Component Analysis, confirmed that the main scale domain has a "leveling off" of eigenvalues after the first factor (factor I), suggesting that the questionnaire should be of a single domain instead of the three domains more likely to be affected by melasma suggested by Balkrishnan et al. (2003), regarding emotional well-beings, social life and recreation and leisure [10].

There was significant positive correlation between the MELASQoL-A scale and the MASI score $(\mathrm{r}=0.41 ; \mathrm{p}=0.0027)$ and the (mMASI) score ( $\mathrm{r}$ $=0.36 ; \mathrm{p}=0.0032)$. This suggests that patients with severe degree of melasma were more likely to have poorer QoL. This was in contrast to the results of other studies reported that the effect of melasma on QoL was not correlated with the severity of melasma. The authors explained that even a small amount of pigmentation can cause a significant emotional effect $[12,13]$.

\section{Conclusion}

The Arabic version of the MELASQoL scale was found to be a reliable and valid measure for evaluating the QoL for Egyptian melasma patients. The evaluation of the QoL in melasma patients, by means of a dermatosis specific instrument, could bring a new comprehension of the results of different treatment modalities aimed to improve the severity of melasma and thus improve the patients' QoL.

\section{Conflicts of interest:}

The authors report no conflicts of interest.

\section{References}

1. Gill TM, Feinstein AR. (1994) A critical appraisal of the quality of quality-of-life measurements.JAMA; 272:619-26.

2. Guyatt GH, Feeny DH, Patrick DL. (1993) Measuring healthrelated quality of life. Ann Intern Med; 118:622-9.

3. Finlay AY, Khan GK. (1994) Dermatology Life Quality Index (DLQI)-a simple practical measure forroutine clinical use. Clin Exp Dermatol; 19:210-6.

4. Finlay AY. (1997) Quality of life measurement in dermatology: a practical guide. Br J Dermatol; 136:305-14.

5. Fleck M, Leal O, Louzada S, Xavier M, Chacha-movich E, Vieira G, et al. (1999) Desenvolvimento daversão em português do instrumento deavaliação de qualidade de vida da OMS (WHOQOL-100). Rev Bras Psiquiatr; 21:19-28.

6. Guillemin F, Bombardier C, Beaton D. (1993) Cross- cultural adaptation of health related qualityof life measures: literature review and proposed guidelines. J Clin Epidemiol; 46: 141732.

7. Moubasher AE, Youssef EM, Abou-Taleb DA. (2014) Qswitched Nd: YAG laser versus trichloroacetic acid peeling in the treatment of melasma among Egyptian patients. Dermatol Surg; 40(8):874-82.

8. Pandya AG, Hynan LS, Bhore R, Riley FC, Guevara IL, Grimes P, Nordlund JJ, Rendon M, Taylor S, Gottschalk RW, Agim NG and Ortonne JP. (2011) Reliability assessment and validation of the Melasma Area and Severity Index (MASI) and a new modified MASI scoring method.J Am Acad Dermatol; 64(1):78-83.

9. Sheth VM, Pandya AG. (2011) Melasma: A comprehensive update, Part I. J Am Acad Dermatol; 65:689-97.

10. Balkrishnan R, McMichael AJ and Camacho FT, Saltzberg F, Housman TS, Grummer S, Feldman SR, Chren MM. (2003) Epidemiology and health services research development and validation of a health-related quality of life instrument for women with melasma. Br. J. Dermatol; 149:572-577.

11. Dominguez AR, Balkrishnan R, Ellzey AR, Pandya AG. (2006) Melasma in Latina patients: Cross-cultural adaptation and validation of a quality-of-life questionnaire in Spanish language. J Am AcadDermatol; 55: 59-66.

12. Cestari TF, Hexsel D, Viegas ML, Azulay L, Hassum K, Almeida ART. (2006) Validation of a melasma quality of life questionnaire for Brazilian Portuguese language: the MelasQoL-BP study and improvement of QoL of melasma patients after triple combination therapy. $\mathrm{Br} \mathrm{J}$ Dermatol; 156(suppl 1):13-20.

13. Freitag FM, Cestari TF, Leopoldo LR, Paludo P, Boza JC. (2008) Effect of melasma on quality of life in a sample of women living insouthern Brazil. J EurAcadDermatolVenereol; 22: 655-62.

14. Misery, Schmitt AM, Boussetta S, Rahhali N, Taieb C. (2010) Melasma: Measure of the Impact on Quality of Life Using the French Version of MELASQOL after Cross-cultural Adaptation. ActaDermato-Venereologica; 90(3): 331-332.

15. Dogramaci, AC,Havlucu DY, Inandi T, Balkrishnan R. (2009) Validation of a melasma quality of life questionnaire for the Turkish language: the MelasQoL-TR study. J Dermatolog Treat; 20(2): 95-99.

16. Pandya A, Berneburg M, Ortonne JP, Picardo M. (2006) Guidelines for clinical trials in melasma. Br J Dermatol; 156: 21.

17. Abou-Taleb DAE, Ibrahim AK, Youssef EM, Moubasher AE. (2017) Reliability, Validity, and Sensitivity to change over time of the Modified Melasma Area and Severity Index Score. Journal of Dermatologic Surgery; 43(2):210-217. 
18. Cronbach L. (1951) Coefficient alpha and the internal structure of the test. Psychometrika; 16(3):194-200.

19. Cronbach L, Shavelson R. (2004) Current thoughts on coefficient alpha. EducPsychol Meas; 64(3):391-418.
20. Bowling A. (2002) Research methods in health. Investigating health and health services. 2nd ed. Buckingham: Open University Press.
Ready to submit your research? Choose Auctores and benefit from:

* fast, convenient online submission

* rigorous peer review by experienced research in your field

* rapid publication on acceptance

* authors retain copyrights

* unique DOI for all articles

* immediate, unrestricted online access

At Auctores, research is always in progress.

Learn more www.auctoresonline.org/journals/journal-of-clinicalresearch-and-reports- 